\title{
Acute Pseudomembranous Candidiasis Front at Cleft Lip and Palate: Are There Additional Correlations? \\ MR Tovani-Palone
}

\begin{abstract}
Cleft lip and palate are the most common craniofacial malformations in humans. The rehabilitation treatment of these anomalies starts early and requires in most cases the performance of surgical procedures. It is essential in this context the maintenance of proper oral hygiene, because larger amounts sites for colonization of microorganisms, so as to promote a greater predisposition for the occurrence of infections such as acute pseudomembranous candidiasis. This fungal disease occurs in children mainly due to immunological immaturity and deficiency of proper oral hygiene. In turn, maintaining oral hygiene of children with clefts often is neglected, whether by fear and / or difficulties of parents and/or caregivers for their realization, especially in postoperative periods. Furthermore, the use of surgical antibiotic prophylaxis and frequent use of antibiotics for the treatment of recurrent otitis together with a diet sometimes different, are feasible factors for major modifications in the balance of the gastrointestinal microbiota resulting in immunomodulation losses in this group of individuals. Therefore during the postoperative periods, intuitively there is a greater predisposition to possible episodes by Candida infection. The oral hygiene preventive maneuvers should be strengthened and initiated during infancy even before the eruption of the first deciduous tooth and must include specific measures to prevent this infectious fungal disease.
\end{abstract}

Keywords: Candidiasis, cleft lip, cleft palate, oral

From: Hospital for Rehabilitation of Craniofacial Anomalies, University of São Paulo, Bauru, Brazil.

Correspondence: Mr Tovani-Palone, Department of Pediatric Dentistry and Public, Health, Hospital for Rehabilitation of Craniofacial Anomalies, University of São Paulo, Bauru, Brazil. State of São Paulo. Fax: +55 14 3234-7818, e-mail: marcos_palone@hotmail.com 


\section{INTRODUCTION}

The oral cavity is the major route of entry of microorganisms, so as to predispose local ecosystems for the occurrence of transient or permanent changes, which may heavily influence the balance of the microflora of the entire gastrointestinal tract (1-5). Examples of such changes are eruption and tooth loss, changes in salivary flow and composition (1), treatment with antimicrobial drugs or medications that affect the tissues and / or action of the immune system (2-6).

In turn, the cleft lip and palate constitute the most prevalent group of craniofacial malformations in humans, and in most cases involve extensive anatomical changes with great morphological variability. Therefore, such defects often require surgical procedures in order to restore aesthetics and function mainly, whose onset usually occurs at very early period (7, 8). In grievance, shows up even in this population more vulnerable to colonization by pathogenic microorganisms, mainly due to the higher number of sites for colonization $(2,3)$.

In this context then, a form of fungal disease called acute pseudomembranous candidiasis requires particular attention, since it is an opportunistic pathology of infectious nature caused by the proliferation of Candida species, especially Candida albicans, relatively common in children $(9,10)$.

Thus, it is appropriate to discuss the peculiarities about favoring of the occurrence of acute pseudomembranous candidiasis front of alterations present in children with cleft lip and palate in order to attend the health professionals involved in the field of this rehabilitation process on the importance and necessity of realization of needed preventive care.

\section{Acute pseudomembranous candidiasis and children with cleft lip and palate}

The acute pseudomembranous candidiasis, when in the oral environment, is characterized by the appearance of detachable white plates, adhered to the buccal mucosa and tongue with 
cottage cheese or curdled milk (9). As the etiological factors this fungic infection may be associated with oral and/or systemic changes, and in children usually develops due to immaturity of the immune system associated with the lack of oral hygiene adequate $(9,10)$. Consequently, in view of the need for strict care regarding oral hygiene during the rehabilitation process of cleft lip and palate, raises an important issue. In this circumstance, the anatomic changes sometimes favor a greater accumulation of food debris (7), in addition to adequate oral hygiene is no longer held in many cases, mainly because of the fear of many mothers and/or caregivers in manipulating the oral cavity amended by fissure (8), a situation aggravated when of the realization of rehabilitative surgeries $(4,11)$. Therefore, care inherent in postoperative critical periods, decisive for the success of treatment, are often overlooked $(4,11)$.

Moreover, children with cleft lip and palate are usually subjected to antibiotic prophylaxis to achieve the rehabilitative surgical procedures $(2,3,5,7)$, and also it's frequent the use of antibiotics for treatment of recurrent otitis, particularly when there is involvement of the palate (5); furthermore these features added to a diet often differentiated (8), are feasible factors to significant changes in gastrointestinal microflora balance, resulting in damage immunomodulation $(6,8)$.

Ergo, during the postoperative periods, intuitively there is a greater predisposition to possible episodes of Candida infection particularly in infants and children with clefts, since the oral environment is particularly humid and in this case tends to be rich in organic matter from debris food in many cases not removed.

Thus, the oral hygiene preventive maneuvers should be strengthened and initiated during infancy even before of the eruption of the first deciduous tooth, through the use of gauze and/or wet clean diaper with filtered water or saline solution (12). Subsequently may 
be provided peculiar instructions on toothbrushing by the changes caused by cracks, directed to each case.

Note also that in addition to general care, such as the adequate cleaning of pacifiers, bottles and humidity control of the nipples between feedings, also are required in order to contemplate the emphasis on the need for cleaning the mucous membranes in the cleft region and its surroundings, as well as brushing the tongue and removal during the night of dental or palate prostheses in use always accordingly cleaned.

\section{Final considerations}

It is of great importance the offering of reinforcement to parents, caregivers and patients, by health professionals involved in the rehabilitation process of cleft lip and palate, about the importance of practice and correct performance of oral hygiene in order to prevent possible infectious processes, particularly during the postoperative periods. Moreover, infections such as acute pseudomembranous candidiasis can infer in impediments to the realization of surgeries, and thus delays in surgical protocols; in addition to the treatment of this infection in cases more complex may require the use of systemic antimicrobials, with the potential to promote additional impacts on the gastrointestinal microbiota and immune modulation of this group of individuals. 


\section{REFERENCES}

1. Spolidorio DMP, Duque C. Microbiologia e Imunologia Geral e Odontológica-Vol. 1Série Abeno. Artes Medicas, 2013.

2. Tovani Palone MR, Saldias Vargas VP. Las fisuras labiopalatinas frente al equilibrio de la microbiota gastrointestinal. Salud Cienc. 2014; 20(8): 875-77.

3. Palone MRT. Fatores modificadores da microbiota gastrintestinal e sua relação com malformações craniofaciais. Rev Fac Ciênc Méd Sorocaba. 2014; 16(2): 107-108.

4. Palone MRT, Silva TR, Vieira NA, Dalben GS. A importância do controle da microbiota bucal e o uso de biomaterial em cirurgias de enxerto alveolar secundário nos pacientes com fissura labiopalatina. Investigação. 2014; 13(2): 19-23.

5. Palone MRT, Silva TR, Vieira NA, Dalben GS. Sequência de Robin e suas repercussões sobre a microbiota bucal: revisão de literatura. Pediatr Mod. 2013; 49(11): 445-450.

6. Palone MRT, Silva TR, Vieira NA, Dalben GS. Influência da composição da microbiota gastrintestinal na imunomodulação de indivíduos com fissura labiopalatina. NBC-Periódico Científico do Núcleo de Biociências. 2014; 3(6): 108109.

7. Tovani-Palone MR, Saldias-Vargas VP, Ribeiro da Silva T. Viabilidade na prescrição de antibióticos para crianças com fissura labiopalatina durante o tratamento odontológico. Rev. Fac. Med. 2015; 63(2): 331-333. doi: http://dx.doi.org/10.15446/revfacmed.v63n2.48624.

8. Tovani-Palone MR. Fissuras labiopalatinas, ganho de peso e cirurgias: leite materno versus fórmulas lácteas. Rev. Fac. Med. 2015; 63(4): 695-698. doi: http://dx.doi.org/10.15446/revfacmed.v63.n4.49226. 
9. Neville B. Patologia oral e maxilofacial. Elsevier Brasil, 2011.

10. Lalla RV, Patton LL, Dongari-Bagtzoglou A. Oral candidiasis: pathogenesis, clinical presentation, diagnosis and treatment strategies. J Calif Dent Assoc. 2013; 41(4): 263 268.

11. Tovani-Palone MR. Fissuras labiopalatinas: pós-operatório com vastos nichos microbiológicos?. Rev. Fac. Med. 2015; 63(1): 117-118. doi: http://dx.doi.org/10.15446/revfacmed.v63n1.47308.

12. Palone MRT, Silva TR, Dalben GS. Cremes dentais infantis: um enfoque para o médico pediatra. Rev Fac Ciênc Méd Sorocaba. 2014; 16(3): 109-110. 